\title{
Crop yield, genetic parameter estimation and selection of sacha inchi in central Amazon ${ }^{1}$
}

\author{
Mágno Sávio Ferreira Valente 2 , Francisco Célio Maia Chaves ${ }^{3}$, \\ Maria Teresa Gomes Lopes ${ }^{2}$, Jaisson Myiosi Oka², Rodney Alexandre Ferreira Rodrigues ${ }^{4}$
}

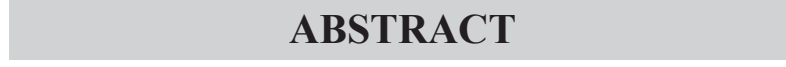

In Brazil, sacha inchi oil is produced by hand from plant materials with no breeding or detailed information about the chemical composition of seeds. In addition, most of the current information on the agronomic traits of this species originates from research carried out in the Peruvian Amazon. In order to promote the research and cultivation of sacha inchi in the Brazilian territory, this study aimed to analyze, in the central Amazon region, different accessions of this oilseed for characteristics of production and quality of fruits and seeds, as well as to estimate genetic parameters, through mixed models, with identification of superior accessions, for breeding purposes. A total of 37 non-domesticated accessions were evaluated in a randomized block design, with five replications and two plants per plot. The average oil content in seeds was $29.07 \%$ and unsaturated fatty acids amounted to $91.5 \%$ of the total fat content. For the yield traits, the estimates of individual broadsense heritability were moderate $(\sim 0.33)$, while the heritability based on the average of progenies resulted in a selective accuracy of approximately 0.85 . The use of the selection index provided simultaneous gains for yield traits $(>40 \%)$ and oil yield. A high genetic variability was observed for the main traits of commercial interest for the species, as well as promising perspectives for the development of superior varieties for agroindustrial use.

KEYWORDS: Plukenetia volubilis L.; Euphorbiaceae; genetic gain; oil yield; plant breeding.

\section{INTRODUCTION}

Sacha inchi (Plukenetia volubilis L. Euphorbiaceae) is an oleaginous woody vine endemic to rain forests of the Peruvian, Colombian, Venezuelan and Brazilian Amazon (Bordignon et al.

\section{RESUMO}

Desempenho produtivo, estimativa de parâmetros genéticos e seleção de sacha inchi na Amazônia central

No Brasil, o óleo de sacha inchi é produzido de forma artesanal, a partir de materiais vegetais, sem qualquer nível de melhoramento ou informações detalhadas sobre a composição química das sementes. Além disso, as informações disponíveis sobre as características agronômicas da espécie são provenientes de pesquisas na Amazônia peruana. Visando a fomentar a pesquisa e o cultivo de sacha inchi em território brasileiro, este trabalho objetivou analisar, na região da Amazônia central, diferentes acessos dessa trepadeira oleaginosa para características de produção e qualidade de frutos e sementes, bem como estimar parâmetros genéticos, por meio de modelos mistos, com identificação de acessos superiores, para fins de melhoramento. Um total de 37 acessos não domesticados foram avaliados em blocos casualizados, com 5 repetições e 2 plantas por parcela. O teor médio de óleo nas sementes foi de $29,07 \%$ e os ácidos graxos insaturados totalizaram 91,5\% do teor total. Para as características de produção, as estimativas de herdabilidade individual, no sentido amplo, foram moderadas $(\sim 0,33)$, e a herdabilidade, com base nas médias das progênies, resultou em acurácia seletiva de, aproximadamente, 0,85. O uso de índice de seleção proporcionou ganhos simultâneos para os caracteres de produção (> 40 \%) e rendimento de óleo. Observou-se alta variabilidade genética para os principais caracteres de interesse comercial da espécie, bem como perspectivas promissoras para o desenvolvimento de variedades superiores para uso agroindustrial.

PALAVRAS-CHAVE: Plukenetia volubilis L.; Euphorbiaceae; ganho genético; rendimento de óleo; melhoramento vegetal.

2012), whose seeds have traditionally been consumed by the indigenous people of Peru in the form of flour and oil (Guillén et al. 2003).

Sacha inchi nuts contain roughly $27 \%$ of protein and $54 \%$ of oil, which is rich in linolenic and linoleic unsaturated fatty acids (up to $93 \%$ of total

1. Manuscript received in Mar./2017 and accepted for publication in Jun./2017 (http://dx.doi.org/10.1590/1983-40632016v4745758).

2. Universidade Federal do Amazonas, Departamento de Produção Animal e Vegetal, Manaus, AM, Brazil.

E-mails: magnosavio@yahoo.com.br,mtglopes@hotmail.com, jaisson.m.ok@hotmail.com.

3. Empresa Brasileira de Pesquisa Agropecuária (Embrapa Amazônia Ocidental), Manaus, AM, Brazil.

E-mail: celio.chaves@embrapa.br.

4. Universidade Estadual de Campinas, Centro Pluridisciplinar de Pesquisas Químicas, Biológicas e Agrícolas, Paulínia, SP, Brazil.E-mail: rodney@cpqba.unicamp.br. 
fat content - Follegatti-Romero et al. 2009). The high unsaturated fatty acid levels in sacha inchi oil reduce postprandial triglyceride levels in adults (Huamán et al. 2008) and help to prevent cardiovascular and neuromuscular diseases (Blondeau \& Schneider 2006, Ramaprasad et al. 2006). The oil is also used as a raw material in the cosmetics industry.

Sacha inchi also has favorable characteristics for reforestation and slope protection against erosion and may be an alternative in degraded areas and family farming programs (Bordignon et al. 2012).

The Peruvian industry has experienced a great demand for oil from sacha inchi seeds, and the Peruvian Amazon Research Institute has described a wide variety of cultivars and ecotypes that differ greatly in leaf area, size and shape of leaves and seeds, and in the ability to produce fruit and oil. Currently, most of the information on the agronomic traits of sacha inchi originate from research in the Peruvian Amazon, and a recent study showed that germplasm from Brazil and Peru cultivated in China differed in adaptability, oil quality and yield potential (Yang et al. 2015).

In Brazil, sacha inchi oil is produced by hand from plant materials with no breeding or detailed information about the chemical composition of seeds, and research has focused on in vitro propagation efficiency (Bordignon et al. 2012, Rodrigues et al. 2014) and seed germination traits (Oliveira et al. 2013, Cardoso et al. 2015) of the species. To date, there are few studies examining the cultivation and agronomic traits of genotypes prospected and cultivated under Brazilian conditions. Therefore, information on fruit yield and oil quality from seeds cultivated in the country are still scarce. Furthermore, to date, no studies have estimated genetic parameters such as individual heritability and yield traits in sacha inchi. These data could help to select the best methods for managing populations, estimate genetic variability and determine the predicted gains from selection.

The use of many plant species with great agribusiness potential is limited to local communities or restricted to certain regions, in part due to a lack of information on high-yield genotypes with agronomic and nutritional traits of interest. The indication of plant materials with superior characteristics may accelerate the adoption of the crop in new areas, and genetic information for traits of interest represent the fundamental basis for a successful breeding program of sacha inchi.
Thus, the objectives of this study were to analyze different sacha inchi accessions from the Brazilian Amazon for yield traits and fruit and seed quality, when cultivated in central Amazon, and to estimate genetic parameters for the identification of agronomically superior accessions for use in breeding programs.

\section{MATERIAL AND METHODS}

The sacha inchi active germplasm bank at Embrapa Amazônia Ocidental (253'29.141''S and 59 58'39.9' W), in Manaus, Amazonas state (AM), Brazil, currently contains 37 P. volubilis accessions collected in several areas of the Amazonas state. Twelve of these accessions are from the same site (Nova Jerusalém farm, in Careiro Castanho, AM $3^{\circ} 31^{\prime} 45.0^{\prime \prime} \mathrm{S}$ and 5949'7.9' W).

For this study, seeds from the 37 nondomesticated accessions were sown in 1-L plastic bags filled with substrate and poultry litter compost at a 3:1 ratio. Seeds were sown at the end of 2012 and seedling emergence was observed at 13 days after sowing (DAS). When seedlings had three pairs of leaves and approximately $40.0 \mathrm{~cm}$ in length, they were planted in the field, in pits previously prepared with poultry litter $\left(0.5 \mathrm{~kg} \mathrm{pit}^{-1}\right)$.

The soil in the experimental area, located at the Embrapa Amazônia Ocidental, is a Yellow Latosol. Soil acidity was corrected with limestone at a rate of $2 t \mathrm{ha}^{-1}$. The crop was established using a vertical trellis support system, at a $3 \mathrm{~m}$ x $3 \mathrm{~m}$ spacing. All cultural practices necessary for crop development were conducted daily according to recommendations by Céspedes (2006), and a drip irrigation system was installed for use only in periods of drought.

The experimental design was a randomized block, with five replications and two plants per plot. Thus, 10 plants from each of the 37 accessions were evaluated, totaling 370 plants. Field work from planting until the last harvest was conducted from January 2013 to December 2014.

Because sacha inchi fruits are dehiscent, fruit harvest was done twice a week. Fruits from plants in the same plot were harvested together and shadedried. The following yield traits were analyzed for 19 consecutive months, from the start of fruit production in June 2013 until the last harvest in December 2014: total number of fruits (fruit plant ${ }^{-1}$ ), total number of seeds (seed plant $\left.{ }^{-1}\right)$ and total fruit weight $\left(\mathrm{g} \mathrm{plant}^{-1}\right)$. 
Seed measurements were taken from a 30 -seed sample from each accession. The seeds had their length, width, thickness and fresh weight recorded using a digital caliper (0.01 $\mathrm{mm}$ precision) and an analytical scale (0.0001 g precision), respectively. Similarly, the average fruit weight $\left(\mathrm{g} \mathrm{fruit}^{-1}\right)$ and number of seeds per fruit (seeds fruit ${ }^{-1}$ ) were determined from a 30 -fruit sample from each accession.

The sacha inchi oil was analyzed by gas chromatography-mass spectrometry (GC-MS) after saponification with $\mathrm{KOH}$, followed by methylation with $\mathrm{NH}_{4} \mathrm{Cl} / \mathrm{H}_{2} \mathrm{SO}_{4}$. Analysis of fatty acid composition was performed after esterification, according to the operating procedures of the Laboratory of Oils and Fats (FEA/Unicamp), based on AOCS (2004) and Hartman \& Lago (1973). The qualitative composition of sacha inchi oil was determined by comparison of sample extract chromatograms with chromatograms from the NIST Mass Spectral Library and Search software v.2.0 (2005), with $96 \%$ as the minimum acceptable agreement. Quantitative composition was determined by area normalization and expressed on a percent mass basis. The average data of the fatty acid composition were obtained from two seed samples of each accession.

Estimates of variance components and genetic parameters were determined using the restricted maximum likelihood method (REML) and best linear unbiased prediction (BLUP) by the statistical genetics software Selegen-REML/BLUP (Resende 2007). Data were analyzed considering a randomized block design, with plot averages and one sampling site, according to the mathematical model $\mathrm{y}=\mathrm{Xr}+\mathrm{Zg}+\mathrm{e}$, where $y$ is the data vector, $r$ the repetition effect vector (assumed to be fixed) added to the overall mean, $g$ the genotypic effect vector (assumed to be random) and $e$ a vector of residual errors (random). The capital letters represent the incidence matrices for the given effects.

The system of linear equations [mixed model equations (MME)] that were used to obtain the solutions of the model were:

$$
\left[\begin{array}{l}
\hat{r} \\
\hat{g}
\end{array}\right]=\left[\begin{array}{cc}
\mathrm{X}^{\prime} \mathrm{X} & \mathrm{X}^{\prime} \mathrm{Z} \\
\mathrm{Z}^{\prime} \mathrm{X} & \mathrm{Z} \mathrm{Z}^{\prime} \mathrm{Z}+\mathrm{I} \frac{\sigma_{e}^{2}}{\sigma_{g}^{2}}
\end{array}\right]^{-1}\left[\begin{array}{c}
\mathrm{X}^{\prime} \mathrm{y} \\
\mathrm{Z}^{\prime} \mathrm{y}
\end{array}\right]
$$

where $\sigma_{\mathrm{g}}^{2}$ is the genetic variance among accessions, $\sigma_{\mathrm{e}}{ }^{2}$ the residual variance and I the identity matrix.
REML estimates of the variance components were obtained using the expectation and maximization algorithm, according to the following expressions:

$$
\begin{aligned}
& \hat{\sigma}_{e}^{2}=\left[\mathrm{y}^{\prime} \mathrm{y}-\hat{\mathrm{r}}^{\prime} \mathrm{X}^{\prime} \mathrm{y}-\hat{\mathrm{g}}^{\prime} \mathrm{Z}^{\prime} \mathrm{y}\right] /[\mathrm{N}-\mathrm{r}(\mathrm{x})] \text { and } \\
& \hat{\sigma}_{g}^{2}=\left[\hat{\mathrm{g}}^{\prime} \hat{\mathrm{g}}+\hat{\sigma}_{e}^{2} \operatorname{tr} \mathrm{C}^{22}\right] / \mathrm{q}
\end{aligned}
$$

where $\mathrm{C}^{22}$ was derived from:

$$
\mathrm{C}^{-1}=\left[\begin{array}{cc}
\mathrm{X}^{\prime} \mathrm{X} & \mathrm{X}^{\prime} \mathrm{Z} \\
\mathrm{Z}^{\prime} \mathrm{X} & \mathrm{Z}^{\prime} \mathrm{Z}+\mathrm{I} \frac{\sigma_{e}^{2}}{\sigma_{g}^{2}}
\end{array}\right]^{-1}=\left[\begin{array}{cc}
\mathrm{C}^{11} & \mathrm{C}^{12} \\
\mathrm{C}^{21} & \mathrm{C}^{22}
\end{array}\right]
$$

which is the generalized inverse of the coefficient MME matrix, $t r$ is the trace of a matrix, $r(x)$ the rank of the X matrix, $q$ the number of individuals and $N$ the total number of observations.

The broad-sense heritability was estimated according to $\hat{h}_{g}^{2}=\hat{\sigma}_{g}^{2} / \hat{\sigma}_{f}^{2}$, where $\hat{\sigma}_{f}^{2}$ is the phenotypic variance individual given by $\hat{\sigma}_{f}^{2}=\hat{\sigma}_{g}^{2}+\hat{\sigma}_{e}^{2}$. The progenies mean heritability was calculated by $\hat{h}_{p m}^{2}=\hat{\sigma}_{g}^{2} /\left[\hat{\sigma}_{g}^{2}+\hat{\sigma}_{e}^{2} / \mathrm{b}\right]$, where $b$ is the number of blocks. The accuracy of accession selection was given by $A c c=\sqrt{\hat{h}_{p m}^{2}}$. The coefficient of genetic variation among accessions $\left(C V_{g i}\right)$, the overall coefficient of variation $\left(C V_{o}\right)$ and the relative coefficient of variation $\left(C V_{r}\right)$ were calculated by $C V_{g i}=100 \sqrt{\hat{\sigma}_{g}^{2}} / \bar{x}, C V_{o}=100 \sqrt{\hat{\sigma}_{e}^{2}} / \bar{x}$ and $C V_{r}=C V_{g} / C V_{o}$, respectively, where $\bar{x}$ is the overall mean.

The indication of superior individuals for the next cycle of selection was based on genotypic values (estimated by the REML/BLUP method) and the rank summation index (Mulamba \& Mock 1978), considering the accession mean heritability and economic weights of 2.0 and 3.0 for yield traits and oil yield, respectively. The genotypic values of each accession were obtained by adding each genotypic effect to the overall mean. The genetic gain was equal to the average of vectors of the predicted genetic effects for the selected accession. The overall mean plus the genetic gain resulted in the improved average population.

\section{RESULTS AND DISCUSSION}

Yield traits for all sacha inchi accessions varied markedly with the time of the year (Figure 1a). 
Initially, the plants produced a few large fruits and the seed weight represented a larger part of the fruit weight. That result is expected in perennial crops, in which the vegetative and reproductive vigor of primary branches is succeeded by a decline in yield as the plant further invests in vegetative structures. In the current study, the average duration of the reproductive phase for sacha inchi under field conditions, in Manaus, was 86 days. Fruit production began at six months after planting (MAP), and there were three large production peaks in the 10th, 15th and 17th MAP (October 2013 and March and May 2014, respectively). Twelve months after the start of fruit production (18 MAP), there was a drastic decline in yield across all accessions, which may have been related to the decrease in rainfall and increase in maximum temperature, up to $36^{\circ} \mathrm{C}$, in the period (Figure 1b).

Even though the species has been shown to grow well at different temperatures, temperatures over $36^{\circ} \mathrm{C}$ may result in drop of flowers and newlyformed fruits (Céspedes 2006). Despite a slight recovery in November 2014, fruit yield declined further, reaching values close to zero in subsequent months of the following year (data not shown). From then to the end of the study period, most plants remained in the vegetative growth phase and no longer produced fruits. In contrast, under the growing conditions of the Peruvian Amazon, sacha inchi does not stop the production for up to 10 years (Céspedes 2006). One possible explanation for the decline in yield is the occurrence of high temperatures in the Manaus region, in 2015.

Overall, there was a small increase in yield after the first year, and total fruit weight per plant only increased from $418.8 \mathrm{~g}$ (12 months) to $461.9 \mathrm{~g}$ (19 months). In contrast, Yang et al. (2015) reported that sacha inchi varieties from Brazil cultivated in China yielded an average of 48 fruits and $200 \mathrm{~g}$ of fruit per plant, in the first year of study. These
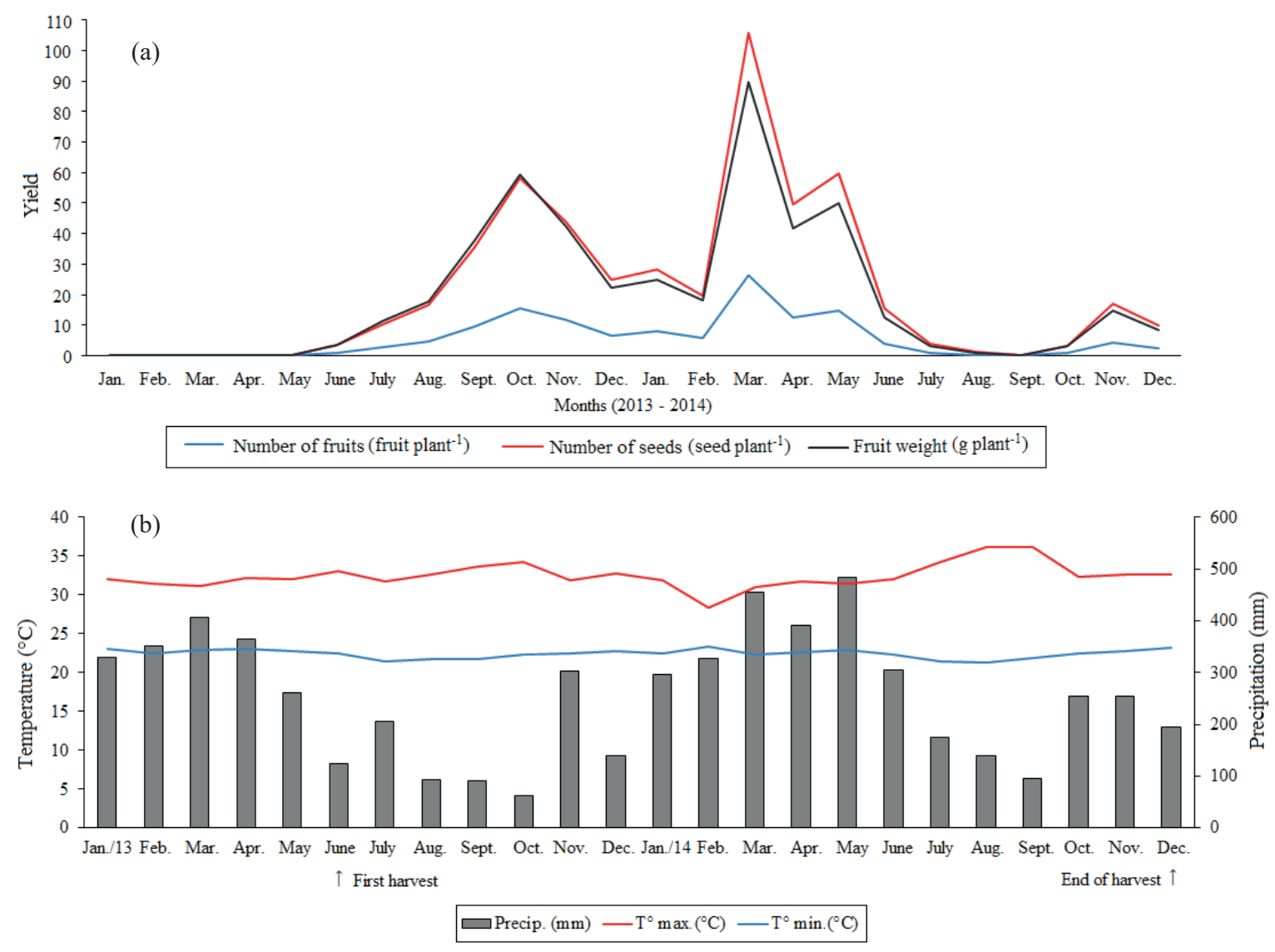

Figure 1. Number of fruits (fruit plant $\left.t^{-1}\right)$, number of seeds (seed plant $\left.{ }^{-1}\right)$ and fruit weight $\left(\mathrm{g} \mathrm{plant}^{-1}\right)$ (a) evaluated monthly in sacha inchi accessions grown in central Amazon, and monthly mean rainfall and maximum and minimum temperatures (b) for the study period, in Manaus, Amazonas state, Brazil. 
figures are less than half of the average values for the current study, for the same period. However, in that study, the authors observed a significant increase in yield (214 fruits and $500 \mathrm{~g} \mathrm{plant}^{-1}$ ) in the third year of study, whereas our study only encompassed 24 months after planting. Considering a planting density of 1,111 plants $h^{-1}$ and an average fruit weight per plant of $418.8 \mathrm{~g}$, the expected yield for the first year was $465.3 \mathrm{~kg}$ of fruits ha-1. This yield is far less than the range of $700-2,000 \mathrm{~kg} \mathrm{ha}^{-1}$ year-1 reported by Céspedes (2006), in Peru. One reason for the higher performance in Peru may be the use of genotypes with a higher level of genetic improvement, if compared to the non-domesticated accessions used in our trials. Intercropping sacha inchi with other crops might be a good alternative for the growing conditions in Brazil, but further research is needed to confirm the economic viability of this cropping system.

In the current study, fruit production was unevenly distributed. Roughly $30 \%$ and $75 \%$ of all plants started producing at 6 and 9 months, respectively, and only from 12 to 13 MAP were all plants fruiting. Whereas fruiting started no later than 9 MAP in accessions 1-24, accessions 25-37 took, on average, 13 MAP to start producing fruits. Accessions 26-37 were collected in the same site at the Nova Jerusalém farm, indicating a relationship between sampling site and fruiting time.

In addition to yield traits, seed and fruit characteristics of the 37 sacha inchi accessions were determined from subsamples including 30 fruits and seeds from each accession (Table 1). The average number of seeds per fruit varied significantly among accessions (3.7-4.0). Sacha inchi fruits typically consist of four lobes (3-7) with one oleaginous seed per lobe (Krivankova et al. 2007). However, the lobes may contain no seeds or seeds may be atrophied, what helps to explain the variation in the number of seeds across accessions. The average fruit weight was $3.42 \mathrm{~g}$, and there was up to $104 \%$ difference between the maximum (accessions 6, 13 and 24) and minimum (accessions 9 and 30) average fruit weights.

Seed characteristics were similar to those reported by Cardoso et al. (2015) for germplasm from Brazil. In the current study, the average seed weight was $0.95 \mathrm{~g}(0.76-1.11 \mathrm{~g})$, within the range reported for germplasm from Brazil, but considerably lower than the $1.33 \mathrm{~g}$ for the Peruvian germplasm (Yang et al. 2015). Measurements for seed length, width and thickness in seeds from Peru were also $21 \%, 12 \%$ and $5 \%$ higher, respectively, than seeds from the current study (Table 1).

Because the main commercial value of sacha inchi is in the oil extracted from its seeds, we also estimated oil yields for each accession (Table 2). Average oil extraction yield was $29.07 \%$, in terms of oil mass (g) per $100 \mathrm{~g}$ of seeds, ranging from $10.20 \%$ (in accession 23) to $57.97 \%$ (in accession 2). This average value is lower than the $54.30 \%$ yield reported by Follegatti-Romero et al. (2009). According to Gutiérrez et al. (2011), differences in oil content may be attributed to differences in subspecies, geographic and climatic conditions, time of seed harvest and extraction method. Oil yields measured by Yang et al. (2015) were higher in germplasm from Brazil $(35.39 \%)$ than from Peru $(34.13 \%)$. In the current study, accession 2 had the highest yield $(57.97 \%)$ and has a great potential for oil production.

Overall, the relative composition of fatty acids in sacha inchi oil was similar to that reported in other studies using germplasm from Peru and Colombia (Follegatti-Romero et al. 2009, Gutiérrez et al. 2011, Maurer et al. 2012). Sacha inchi oil is one of the richest in unsaturated fatty acids and, in this study, these amounted to $91.5 \%$ of the total fat content. This composition makes it special for use as a food supplement. The average linolenic acid content was $45.24 \%$ (sacha inchi oil is one of the richest sources of omega-3). Linoleic (omega-6) and oleic (omega-9) acids were also found at high concentrations (36.44 \% and $9.83 \%$, respectively). These results are similar to those reported by Yang et al. (2015), but the omega-3 content was slightly lower and omega- 6 and omega- 9 contents were higher than in the studies by Follegatti-Romero et al. (2009) (50.41\%, 34.08\% and $8.41 \%$, respectively) and Gutiérrez et al. (2011) (50.8\%, $33.4 \%$ and $9.1 \%$ ). It is important to report that there was no significant correlation between the oil yield and fatty acid composition with any of the biometric and fruit and seed yield traits. This result indicates that it is possible to select for both traits independently.

In order to identify genetically superior accessions, genetic parameters were estimated using mixed models procedures. Moderate individual broad-sense heritability values $(0.33-0.36)$ were estimated for all traits, which may be partly explained by the large variation in yield among plants within accessions (Table 3). The $\hat{h}_{g}^{2}$ estimates, when applied individually during the early stages of sacha inchi 
breeding, may contribute to the identification of promising new families for these traits and yield a greater number of genotypes for potential use as new cultivars. However, when the individual heritability is not high, the selection is more effective if based on familial information, in which most of the phenotypic variation may be explained by genetic components (Oliveira et al. 2014). Higher heritability values (0.72-0.73) were obtained using the average among progenies as a selection unit, suggesting a good potential for selection in sacha inchi. The selected accuracy estimated from the square root of mean progenies heritabilities was approximately 0.85 for all traits, indicating that traits are constant over time across superior accessions, and that their expression is under genetic control.

The presence of genetic variability might be confirmed and quantified by the coefficient of genetic variation, which expresses the magnitude of genetic variation, in relation to the trait average. The coefficient of genetic variation across accessions was greater than $40 \%$ for all traits, confirming the

Table 1. Average values for fruit and seed traits in 37 sacha inchi (Plukenetia volubilis L.) accessions.

\begin{tabular}{|c|c|c|c|c|c|c|c|c|c|c|c|c|}
\hline Accession & Seeds per & fruit (n) & Fruit wei & ght (g) & Seed weig & ght $(\mathrm{g})$ & Seed length (1 & $\mathrm{mm})$ & Seed width & $(\mathrm{mm})$ & Seed thick & kness (mm) \\
\hline 1 & 3.92 & $\mathrm{a} \dagger$ & 3.10 & $\mathrm{~d}$ & 1.04 & $\mathrm{a}$ & 18.21 & $\mathrm{c}$ & 15.38 & $\mathrm{~b}$ & 9.08 & $\mathrm{a}$ \\
\hline 2 & 3.92 & $\mathrm{a}$ & 3.77 & $\mathrm{~b}$ & 0.93 & $\mathrm{c}$ & 17.81 & $\mathrm{c}$ & 14.82 & $\mathrm{c}$ & 8.56 & $\mathrm{~b}$ \\
\hline 3 & 3.76 & $\mathrm{~b}$ & 3.02 & $\mathrm{~d}$ & 0.99 & $\mathrm{~b}$ & 17.90 & $\mathrm{c}$ & 15.37 & $\mathrm{~b}$ & 8.56 & $\mathrm{~b}$ \\
\hline 4 & 3.82 & $\mathrm{~b}$ & 3.52 & $\mathrm{c}$ & 0.98 & $\mathrm{~b}$ & 18.29 & $\mathrm{c}$ & 15.22 & $\mathrm{~b}$ & 8.35 & $\mathrm{~b}$ \\
\hline 5 & 3.94 & $\mathrm{a}$ & 3.58 & $\mathrm{~b}$ & 1.11 & $\mathrm{a}$ & 19.61 & $\mathrm{a}$ & 15.89 & $\mathrm{a}$ & 8.94 & $\mathrm{a}$ \\
\hline 6 & 3.84 & $\mathrm{~b}$ & 3.91 & $\mathrm{a}$ & 1.04 & $\mathrm{a}$ & 18.28 & $\mathrm{c}$ & 15.46 & $\mathrm{a}$ & 9.40 & a \\
\hline 7 & 3.80 & $\mathrm{~b}$ & 3.67 & $\mathrm{~b}$ & 0.99 & $\mathrm{~b}$ & 17.70 & $\mathrm{c}$ & 15.07 & $\mathrm{c}$ & 9.05 & $\mathrm{a}$ \\
\hline 8 & 3.81 & $\mathrm{~b}$ & 3.60 & $\mathrm{~b}$ & 0.91 & $\mathrm{c}$ & 16.94 & $\mathrm{~d}$ & 15.15 & $\mathrm{~b}$ & 8.31 & $\mathrm{~b}$ \\
\hline 9 & 3.78 & $\mathrm{~b}$ & 2.19 & $\mathrm{e}$ & 0.82 & $\mathrm{~d}$ & 16.43 & $\mathrm{e}$ & 15.13 & $\mathrm{~b}$ & 7.77 & $\mathrm{c}$ \\
\hline 10 & 4.03 & a & 3.60 & $\mathrm{~b}$ & 0.90 & $\mathrm{c}$ & 17.51 & $\mathrm{~d}$ & 15.23 & $\mathrm{~b}$ & 7.49 & $\mathrm{~d}$ \\
\hline 11 & 3.82 & $\mathrm{~b}$ & 3.42 & $\mathrm{c}$ & 0.90 & $\mathrm{c}$ & 17.18 & $\mathrm{~d}$ & 14.93 & $\mathrm{c}$ & 7.85 & $\mathrm{c}$ \\
\hline 12 & 3.75 & $\mathrm{~b}$ & 3.63 & $\mathrm{~b}$ & 1.00 & $\mathrm{~b}$ & 18.42 & $\mathrm{c}$ & 15.24 & $\mathrm{~b}$ & 8.31 & b \\
\hline 13 & 3.88 & $\mathrm{a}$ & 3.85 & $\mathrm{a}$ & 0.93 & $\mathrm{c}$ & 17.70 & $\mathrm{c}$ & 15.14 & $\mathrm{~b}$ & 8.40 & $\mathrm{~b}$ \\
\hline 14 & 3.84 & $\mathrm{~b}$ & 3.33 & $\mathrm{c}$ & 0.94 & $\mathrm{c}$ & 17.25 & $\mathrm{~d}$ & 15.39 & $\mathrm{~b}$ & 8.65 & $\mathrm{~b}$ \\
\hline 15 & 3.79 & $\mathrm{~b}$ & 3.32 & $\mathrm{c}$ & 0.93 & $\mathrm{c}$ & 17.45 & $\mathrm{~d}$ & 14.92 & $\mathrm{c}$ & 8.39 & $\mathrm{~b}$ \\
\hline 16 & 3.79 & $\mathrm{~b}$ & 3.25 & $\mathrm{c}$ & 0.87 & $\mathrm{c}$ & 16.50 & $\mathrm{e}$ & 14.86 & $\mathrm{c}$ & 8.42 & $\mathrm{~b}$ \\
\hline 17 & 3.80 & $\mathrm{~b}$ & 3.53 & $\mathrm{c}$ & 0.96 & $\mathrm{~b}$ & 17.97 & $\mathrm{c}$ & 14.98 & $\mathrm{c}$ & 8.64 & $\mathrm{~b}$ \\
\hline 18 & 3.86 & $\mathrm{~b}$ & 3.37 & $\mathrm{c}$ & 0.96 & $\mathrm{~b}$ & 18.15 & $\mathrm{c}$ & 15.26 & $\mathrm{~b}$ & 8.08 & c \\
\hline 19 & 3.70 & $\mathrm{~b}$ & 3.76 & $b$ & 1.02 & $b$ & 17.68 & $\mathrm{c}$ & 15.51 & $\mathrm{a}$ & 9.26 & $\mathrm{a}$ \\
\hline 20 & 3.90 & $\mathrm{a}$ & 3.01 & $\mathrm{~d}$ & 0.81 & $\mathrm{~d}$ & 16.18 & $\mathrm{e}$ & 14.93 & $\mathrm{c}$ & 7.39 & d \\
\hline 21 & 3.85 & $\mathrm{~b}$ & 3.72 & $\mathrm{~b}$ & 0.94 & $\mathrm{c}$ & 17.55 & $\mathrm{~d}$ & 15.19 & $\mathrm{~b}$ & 8.61 & $\mathrm{~b}$ \\
\hline 22 & 3.73 & $\mathrm{~b}$ & 3.34 & $\mathrm{c}$ & 0.76 & $\mathrm{~d}$ & 16.48 & $\mathrm{e}$ & 14.16 & $\mathrm{~d}$ & 7.79 & $\mathrm{c}$ \\
\hline 23 & 3.84 & $\mathrm{~b}$ & 3.41 & $\mathrm{c}$ & 0.97 & $\mathrm{~b}$ & 18.12 & $\mathrm{c}$ & 15.16 & $\mathrm{~b}$ & 8.58 & $\mathrm{~b}$ \\
\hline 24 & 3.96 & $\mathrm{a}$ & 4.11 & $\mathrm{a}$ & 0.96 & $\mathrm{~b}$ & 17.59 & $\mathrm{~d}$ & 15.33 & $\mathrm{~b}$ & 8.48 & $\mathrm{~b}$ \\
\hline 25 & 3.97 & $\mathrm{a}$ & 2.90 & $\mathrm{~d}$ & 0.99 & b & 18.80 & $\mathrm{~b}$ & 15.36 & $\mathrm{~b}$ & 8.64 & $\mathrm{~b}$ \\
\hline 26 & 3.90 & $\mathrm{a}$ & 3.17 & $\mathrm{~d}$ & 0.95 & $\mathrm{c}$ & 18.19 & $\mathrm{c}$ & 15.52 & $\mathrm{a}$ & 8.36 & $\mathrm{~b}$ \\
\hline 27 & 3.90 & $\mathrm{a}$ & 3.48 & $\mathrm{c}$ & 0.89 & $\mathrm{c}$ & 17.13 & $\mathrm{~d}$ & 15.02 & $\mathrm{c}$ & 8.08 & $\mathrm{c}$ \\
\hline 28 & 3.86 & $\mathrm{~b}$ & 3.62 & $\mathrm{~b}$ & 0.93 & $\mathrm{c}$ & 17.07 & $\mathrm{~d}$ & 15.03 & $\mathrm{c}$ & 8.45 & $\mathrm{~b}$ \\
\hline 29 & 3.77 & $\mathrm{~b}$ & 3.06 & $\mathrm{~d}$ & 0.91 & $\mathrm{c}$ & 17.25 & $\mathrm{~d}$ & 14.89 & $\mathrm{c}$ & 7.98 & $\mathrm{c}$ \\
\hline 30 & 3.91 & $\mathrm{a}$ & 2.01 & $\mathrm{e}$ & 0.91 & $\mathrm{c}$ & 17.14 & $\mathrm{~d}$ & 15.24 & $\mathrm{~b}$ & 8.70 & $\mathrm{~b}$ \\
\hline 31 & 3.91 & $\mathrm{a}$ & 3.47 & $\mathrm{c}$ & 1.04 & $\mathrm{a}$ & 18.11 & $\mathrm{c}$ & 15.52 & $\mathrm{a}$ & 8.83 & $\mathrm{a}$ \\
\hline 32 & 3.81 & $\mathrm{~b}$ & 3.44 & $\mathrm{c}$ & 1.03 & $\mathrm{a}$ & 18.25 & $\mathrm{c}$ & 15.26 & $\mathrm{~b}$ & 8.78 & $\mathrm{~b}$ \\
\hline 33 & 3.95 & $\mathrm{a}$ & 3.72 & $\mathrm{~b}$ & 0.89 & $\mathrm{c}$ & 16.83 & e & 15.00 & $\mathrm{c}$ & 8.61 & $\mathrm{~b}$ \\
\hline 34 & 3.99 & $\mathrm{a}$ & 3.39 & $\mathrm{c}$ & 0.91 & $\mathrm{c}$ & 17.45 & $\mathrm{~d}$ & 15.07 & $\mathrm{c}$ & 8.19 & $\mathrm{c}$ \\
\hline 35 & 3.91 & $\mathrm{a}$ & 3.61 & $\mathrm{~b}$ & 1.10 & $\mathrm{a}$ & 18.13 & $\mathrm{c}$ & 15.48 & $\mathrm{a}$ & 9.20 & $\mathrm{a}$ \\
\hline 36 & 3.83 & $\mathrm{~b}$ & 3.70 & $\mathrm{~b}$ & 0.97 & $\mathrm{~b}$ & 17.88 & $\mathrm{c}$ & 15.27 & $\mathrm{~b}$ & 8.34 & $\mathrm{~b}$ \\
\hline 37 & 4.00 & $\mathrm{a}$ & 3.79 & $\mathrm{~b}$ & 0.90 & $\mathrm{c}$ & 17.04 & $\mathrm{~d}$ & 15.14 & $\mathrm{~b}$ & 8.51 & $\mathrm{~b}$ \\
\hline Mean & 3.86 & & 3.42 & & 0.95 & & 17.63 & & 15.18 & & 8.46 & \\
\hline CV (\%) & 3.65 & & 6.16 & & 15.99 & & 8.19 & & 4.71 & & 10.15 & \\
\hline
\end{tabular}


potential of the species for selection, i.e., genetic gain is expected by applying adequate selection procedures. The overall coefficients of variation ranged 56.58-62.92 \% (Table 3), consistently with the quantitative and polygenic nature of yield traits, greatly affected by environmental factors.

Selection strategies may be used to identify promising genotypes in sacha inchi. The breeder may be interested in working with populations formed by descendants of selected individuals. In this case, for segregating populations derived from the crossing of superior genotypes, it is important to estimate the additive genetic values, considering that only these additive effects are transmitted to offspring via sexual reproduction. In our analysis, models that assumed that progenies were halfsib had negative residual variance estimates, so the additive variance could not be estimated. An alternative would be to use models in which the species is assumed to have a mixed reproductive system. However, no study has estimated natural selfing rates in sacha inchi. Due to these problems,

Table 2. Oil yield and fatty acid composition in 37 sacha inchi (Plukenetia volubilis L.) accessions.

\begin{tabular}{|c|c|c|c|c|c|c|}
\hline \multirow{2}{*}{ Accession } & \multirow{2}{*}{ Oil yield (g 100 g) } & \multicolumn{5}{|c|}{ Relative composition of fatty acids (\%) } \\
\hline & & Palmitic (C16) & Stearic $(\mathrm{C} 18)$ & Oleic $(\mathrm{C} 18: 1)$ & Linoleic (C18:2) & Linolenic (C18:3) \\
\hline 1 & 34.67 & 4.60 & 3.90 & 12.04 & 33.36 & 45.34 \\
\hline 2 & 57.97 & 4.05 & 4.04 & 12.38 & 35.04 & 43.72 \\
\hline 3 & 32.93 & 4.59 & 4.00 & 11.17 & 36.33 & 42.88 \\
\hline 4 & 31.08 & 4.89 & 3.75 & 9.97 & 36.50 & 44.53 \\
\hline 5 & 28.81 & 4.64 & 3.37 & 10.24 & 37.13 & 43.90 \\
\hline 6 & 33.21 & 4.84 & 4.34 & 10.34 & 36.91 & 42.81 \\
\hline 7 & 34.24 & 4.99 & 4.16 & 9.62 & 37.21 & 44.01 \\
\hline 8 & 31.58 & 4.77 & 4.00 & 9.15 & 36.56 & 45.14 \\
\hline 9 & 26.59 & 4.74 & 4.33 & 9.93 & 37.58 & 43.06 \\
\hline 10 & 30.77 & 4.69 & 3.84 & 9.70 & 37.93 & 43.42 \\
\hline 11 & 19.18 & 4.58 & 3.85 & 11.58 & 33.03 & 46.27 \\
\hline 12 & 32.63 & 4.44 & 3.64 & 10.22 & 36.12 & 45.58 \\
\hline 13 & 29.27 & 4.51 & 3.79 & 11.06 & 36.92 & 43.72 \\
\hline 14 & 27.71 & 4.95 & 3.70 & 10.86 & 38.35 & 42.14 \\
\hline 15 & 23.02 & 4.59 & 4.22 & 10.26 & 32.03 & 48.90 \\
\hline 16 & 24.90 & 4.86 & 4.23 & 8.52 & 34.80 & 47.59 \\
\hline 17 & 34.18 & 4.55 & 3.79 & 9.87 & 34.88 & 46.60 \\
\hline 18 & 32.77 & 4.64 & 3.69 & 9.66 & 35.04 & 46.65 \\
\hline 19 & 33.09 & 4.26 & 3.87 & 8.88 & 38.17 & 44.83 \\
\hline 20 & 28.70 & 3.44 & 3.16 & 9.20 & 39.04 & 45.15 \\
\hline 21 & 34.64 & 3.81 & 3.03 & 7.60 & 37.01 & 48.55 \\
\hline 22 & - & - & - & - & - & - \\
\hline 23 & 10.20 & 3.88 & 2.98 & 9.01 & 34.59 & 49.55 \\
\hline 24 & 15.38 & 4.05 & 3.66 & 8.39 & 36.29 & 47.61 \\
\hline 25 & 14.15 & 3.70 & 3.22 & 8.65 & 34.51 & 49.92 \\
\hline 26 & 32.50 & 4.20 & 2.98 & 8.33 & 39.82 & 44.67 \\
\hline 27 & 32.11 & 4.03 & 3.23 & 7.34 & 37.70 & 47.71 \\
\hline 28 & 30.58 & 4.56 & 3.55 & 10.10 & 36.51 & 44.47 \\
\hline 29 & 20.15 & 4.51 & 4.20 & 9.69 & 36.70 & 44.16 \\
\hline 30 & 32.36 & 4.47 & 3.79 & 10.00 & 36.49 & 44.53 \\
\hline 31 & 26.41 & 4.32 & 3.93 & 11.04 & 35.46 & 44.54 \\
\hline 32 & 31.08 & 4.27 & 3.58 & 10.19 & 38.28 & 42.91 \\
\hline 33 & 20.32 & 4.12 & 3.69 & 10.20 & 38.36 & 42.89 \\
\hline 34 & 31.69 & 4.23 & 3.60 & 9.40 & 38.21 & 43.78 \\
\hline 35 & 34.15 & 4.18 & 4.11 & 10.68 & 38.04 & 42.31 \\
\hline 36 & 23.90 & 4.06 & 3.51 & 9.67 & 35.12 & 46.90 \\
\hline 37 & 29.47 & 3.67 & 3.15 & 8.80 & 35.78 & 47.83 \\
\hline Mean & 29.07 & 4.38 & 3.72 & 9.83 & 36.44 & 45.24 \\
\hline $\mathrm{SD}$ & 7.97 & 0.39 & 0.39 & 1.13 & 1.73 & 2.13 \\
\hline
\end{tabular}


the accessions selection was made based on the genotypic values (containing the additive and dominance variances) by the individual BLUP procedure. The genotypic values and improved population mean values of the 37 sacha inchi accessions are presented in Table 4.

High correlation $(>0.98)$ and similarity between superior accessions was observed among yield traits. Genotypic values ranged 67.03-254.45 for number of fruits, 259.58-939.14 for number of seeds and 210.50-953.49 for fruit weight. The selection of the top 10 individuals for these yield traits would provide an increase in the mean population of $47.21 \%, 46.49 \%$ and $53.28 \%$, respectively for number of fruits, number of seeds and fruit weight.

Accessions with higher genotypic values are indicated for clonal propagation, since genotypic values capitalize the additive and dominance effects, which are fully transmitted to the next generation only through vegetative propagation. The use of in vitro cultivation has shown to be promising in the production of seedlings of the species (Bordignon et al. 2012). Rodrigues et al. (2014) observed an increasing yield and greater uniformity of in vitropropagated plants. These authors also reported that sacha inchi plants propagated in vitro had more evenly distributed flowering and started earlier than plants grown from seeds.

In the current study, the use of selection index was also considered. Ten of the 37 accessions were selected by the rank summation index (Mulamba \& Mock 1978) (Table 5). The index enabled the selection of accessions with higher averages for all traits. Selection gains were greater than $40 \%$ for yield traits, what may be attributed to the fact that non-domesticated genetic resources were evaluated. This result indicates the existence of great genetic variability to be exploited. However, we were not able to estimate selection gains for oil yield, because the heritability value estimated for this trait was not available.

Accessions 2, 3, 6, 7, 8, 13, 16, 17, 19 and 21 were selected in the rank summation index and showed $80 \%$ and $70 \%$ agreement with accessions selected by direct selection for total fruit weight or by other traits, respectively. This high agreement was already expected because of the high correlation between fruit and seed yield traits $(>0.98)$ and the positive correlation between these traits and oil yield $(\sim 0.2)$. It should also be noted that no accessions prospected at the Nova Jerusalém site (accessions 26-37) were indicated for selection. Overall, genotypes collected in the interior of the Amazonas state (accessions 1-25) were more promising in our evaluations, and these regions should be prioritized in future collections. Rodrigues et al. (2013), in a study of the genetic diversity of these accessions by genetic markers, also identified a geographic structure among accessions, in relation to their origin.

We believe that the information on agronomic traits and oil quality of genotypes prospected and cultivated under Brazilian conditions will be of great importance in the advancement of this crop in the country. The indication of superior plant materials may also accelerate the adoption of the crop in new areas, and some genetic parameters presented will contribute to the identification of promising progenies for potential use as new cultivars or as source of

Table 3. Genetic parameter estimates for total number of fruits (fruits plant $t^{-1}$ ), total number of seeds (seeds plant ${ }^{-1}$ ) and total fruit weight (g plant ${ }^{-1}$ ), in 37 sacha inchi (Plukenetia volubilis L.) accessions.

\begin{tabular}{|c|c|c|c|}
\hline Genetic parameter $\dagger$ & Total number of fruits & Total number of seeds & Total fruit weight \\
\hline$\hat{\sigma}_{g}^{2}$ & $3,057.9872$ & $42,423.9165$ & $45,630.4549$ \\
\hline$\hat{\sigma}_{e}^{g}$ & $5,945.6011$ & $82,288.9001$ & $81,807.1464$ \\
\hline$\hat{\sigma}_{f}^{2}$ & $9,003.5883$ & $124,712.8166$ & $127,437.6013$ \\
\hline$\hat{h}_{g}^{2}$ & 0.3396 & 0.3402 & 0.3581 \\
\hline $\begin{array}{c}g \\
\hat{h}_{p m}^{2} \\
\end{array}$ & 0.7200 & 0.7205 & 0.7361 \\
\hline Acc & 0.8485 & 0.8488 & 0.8579 \\
\hline$C V_{g}(\%)$ & 41.68 & 40.63 & 46.25 \\
\hline$C V_{o}^{g}(\%)$ & 58.12 & 56.58 & 62.92 \\
\hline$C V_{r}^{\circ}(\%)$ & 0.72 & 0.72 & 0.75 \\
\hline $\bar{x}$ & 132.6730 & 506.9784 & 461.8860 \\
\hline
\end{tabular}

$\dagger \hat{\sigma}_{\mathrm{g}}^{2}$ : genetic variance among accessions; $\hat{\sigma}_{\mathrm{e}}^{2}$ : residual variance; $\hat{\sigma}_{\mathrm{f}}^{2}$ : individual phenotypic variance; $\hat{h}_{\mathrm{g}}^{2}$ : individual broad-sense heritability; $\hat{h}_{p m}^{2}:$ progenies mean heritability, assuming full survival; $A c c$ : accession selective accuracy, assuming full survival; $C V_{g}$ : coefficient of genetic variation among accessions; $C V_{o}$ : overall coefficient of variation; $C V_{r}$ : relative coefficient of variation; $\overline{\mathrm{x}}$ overall mean. 
Table 4. Rank of sacha inchi accessions and their genotypic values $(\mathrm{u}+\mathrm{g})$ and new averages (NA) for total number of fruits (fruit plant $\left.^{-1}\right)$, total number of seeds (seed plant $\left.{ }^{-1}\right)$ and total fruit weight $\left(\mathrm{g}\right.$ plant $\left.\mathrm{t}^{-1}\right)$ evaluated in central Amazon, from June 2013 to December 2014.

\begin{tabular}{|c|c|c|c|c|c|c|c|c|c|}
\hline \multirow{2}{*}{ Rank } & \multicolumn{3}{|c|}{ Total number of fruits } & \multicolumn{3}{|c|}{ Total number of seeds } & \multicolumn{3}{|c|}{ Total fruit weight } \\
\hline & Accession & $\mathrm{u}+\mathrm{g}$ & $\mathrm{NA} \uparrow$ & Accession & $\mathrm{u}+\mathrm{g}$ & NA & Accession & $\mathrm{u}+\mathrm{g}$ & NA \\
\hline 1 & 19 & 254.45 & 254.45 & 19 & 939.14 & 939.14 & 19 & 953.49 & 953.49 \\
\hline 2 & 7 & 234.36 & 244.40 & 7 & 888.20 & 913.67 & 7 & 876.34 & 914.92 \\
\hline 3 & 16 & 230.54 & 239.78 & 16 & 867.53 & 898.29 & 21 & 816.32 & 882.05 \\
\hline 4 & 21 & 218.88 & 234.56 & 21 & 837.84 & 883.18 & 16 & 764.25 & 852.60 \\
\hline 5 & 6 & 185.18 & 224.68 & 6 & 708.80 & 848.30 & 6 & 726.96 & 827.47 \\
\hline 6 & 15 & 180.29 & 217.28 & 23 & 678.33 & 819.97 & 13 & 632.18 & 794.92 \\
\hline 7 & 23 & 176.04 & 211.39 & 15 & 675.73 & 799.37 & 15 & 605.79 & 767.90 \\
\hline 8 & 13 & 165.96 & 205.71 & 13 & 643.17 & 779.84 & 23 & 603.82 & 747.39 \\
\hline 9 & 20 & 157.39 & 200.34 & 20 & 606.13 & 760.54 & 2 & 558.21 & 726.37 \\
\hline 10 & 17 & 150.04 & 195.31 & 2 & 581.71 & 742.66 & 17 & 542.59 & 708.00 \\
\hline 11 & 2 & 148.96 & 191.10 & 17 & 565.86 & 726.59 & 8 & 529.88 & 691.80 \\
\hline 12 & 8 & 148.60 & 187.56 & 8 & 562.04 & 712.87 & 10 & 517.68 & 677.29 \\
\hline 13 & 10 & 141.26 & 184.00 & 10 & 561.53 & 701.23 & 20 & 502.36 & 663.84 \\
\hline 14 & 3 & 140.40 & 180.88 & 4 & 534.88 & 689.35 & 4 & 495.46 & 651.81 \\
\hline 15 & 4 & 140.04 & 178.16 & 3 & 528.10 & 678.60 & 12 & 472.79 & 639.88 \\
\hline 16 & 12 & 131.76 & 175.26 & 11 & 489.99 & 666.81 & 11 & 445.72 & 627.74 \\
\hline 17 & 11 & 129.02 & 172.54 & 12 & 489.05 & 656.36 & 3 & 438.13 & 616.59 \\
\hline 18 & 22 & 121.53 & 169.70 & 22 & 455.05 & 645.17 & 24 & 418.50 & 605.58 \\
\hline 19 & 1 & 115.27 & 166.84 & 1 & 441.21 & 634.44 & 22 & 415.94 & 595.60 \\
\hline 20 & 30 & 111.81 & 164.09 & 30 & 432.78 & 624.35 & 5 & 385.59 & 585.10 \\
\hline 21 & 32 & 110.95 & 161.56 & 5 & 424.28 & 614.83 & 32 & 377.75 & 575.23 \\
\hline 22 & 24 & 109.00 & 159.17 & 32 & 419.89 & 605.97 & 33 & 377.69 & 566.25 \\
\hline 23 & 5 & 108.72 & 156.98 & 24 & 419.60 & 597.86 & 28 & 371.95 & 557.80 \\
\hline 24 & 14 & 108.57 & 154.96 & 14 & 417.08 & 590.33 & 14 & 367.30 & 549.86 \\
\hline 25 & 18 & 105.40 & 152.98 & 33 & 408.79 & 583.07 & 1 & 366.30 & 542.52 \\
\hline 26 & 9 & 104.83 & 151.12 & 28 & 403.17 & 576.15 & 18 & 358.33 & 535.44 \\
\hline 27 & 28 & 104.61 & 149.40 & 18 & 401.59 & 569.68 & 35 & 341.11 & 528.24 \\
\hline 28 & 33 & 104.54 & 147.80 & 9 & 394.60 & 563.43 & 37 & 330.40 & 521.17 \\
\hline 29 & 26 & 100.22 & 146.16 & 26 & 388.91 & 557.41 & 31 & 330.13 & 514.59 \\
\hline 30 & 35 & 97.12 & 144.52 & 35 & 375.29 & 551.34 & 26 & 327.46 & 508.35 \\
\hline 31 & 31 & 96.12 & 142.96 & 31 & 372.70 & 545.58 & 29 & 302.44 & 501.71 \\
\hline 32 & 29 & 94.60 & 141.45 & 29 & 359.51 & 539.76 & 34 & 279.24 & 494.75 \\
\hline 33 & 37 & 90.86 & 139.92 & 37 & 357.06 & 534.23 & 30 & 276.58 & 488.14 \\
\hline 34 & 34 & 83.01 & 138.25 & 34 & 323.70 & 528.04 & 9 & 275.61 & 481.89 \\
\hline 35 & 36 & 72.21 & 136.36 & 36 & 277.37 & 520.87 & 36 & 256.51 & 475.45 \\
\hline 36 & 27 & 69.33 & 134.50 & 27 & 268.01 & 513.85 & 27 & 238.46 & 468.87 \\
\hline 37 & 25 & 67.03 & 132.67 & 25 & 259.58 & 506.98 & 25 & 210.50 & 461.89 \\
\hline
\end{tabular}

$\uparrow$ New average of the population after selection.

Table 5. Genetic gain estimates and accessions selected by the rank summation index (Mulamba \& Mock 1978) for total number of fruits (fruits plant $\left.{ }^{-1}\right)$, total number of seeds (seeds plant $\left.{ }^{-1}\right)$, total fruit weight (g plant $\left.{ }^{-1}\right)$ and oil yield (g $\left.100 \mathrm{~g}^{-1}\right)$, in $37 \mathrm{sacha}^{-}$ inchi (Plukenetia volubilis L.) accessions.

\begin{tabular}{lcccc}
\hline \multicolumn{1}{c}{ Parameter } & $\begin{array}{c}\text { Total number } \\
\text { of fruits }\end{array}$ & $\begin{array}{c}\text { Total number } \\
\text { of seeds }\end{array}$ & $\begin{array}{c}\text { Total fruit } \\
\text { weight }\end{array}$ & $\begin{array}{c}\text { Oil } \\
\text { yield }\end{array}$ \\
\hline Original mean & 132.67 & 506.98 & 461.89 & 29.07 \\
Mean of selected genotypes & 209.15 & 791.87 & 763.42 & 34.60 \\
Progenies mean heritability (\%) & 72.00 & 72.05 & 73.61 & - \\
Selection gain & 55.07 & 205.27 & 221.95 & - \\
Selection gain (\%) & 41.50 & 40.49 & 48.05 & - \\
\hline Selected accessions & & $2,3,6,7,8,13,16,17,19$, and 21 & \multirow{2}{*}{80.00} \\
\hline Coincidence (\%) of accessions selected by direct & \multirow{2}{*}{70.00} & 70.00 & & \multirow{2}{*}{70.00} \\
selection x Mulamba \& Mock & & & &
\end{tabular}


plant material for in vitro propagation. However, further knowledge about the mating system and the distribution of genetic variation among and within progenies is still needed. A technique to standardize the flowering process would also be important to facilitate the harvest process and enable a uniform production.

\section{CONCLUSIONS}

1. The production of fruits and seeds in central Amazon was unevenly distributed over time, and yields were lower than under Peruvian growing conditions;

2. Overall, accessions collected in the interior of the Amazonas state were the most productive ones and their fruiting started earlier;

3. High estimates of heritabilities for yield traits based on accessions average evidenced favorable conditions for selection, allowing a selective accuracy of $85 \%$;

4. There is high genetic variability for the main commercial traits of interest in sacha inchi, which may result in significant gains, depending on the selection procedure adopted.

\section{ACKNOWLEDGMENTS}

The authors thank the Conselho Nacional de Desenvolvimento Científico e Tecnológico (CNPq) and Fundação de Amparo à Pesquisa do Estado do Amazonas (FAPEAM), for financial support.

\section{REFERENCES}

AMERICAN OIL CHEMISTS' SOCIETY (AOCS). Official methods and recommended practices of the American Oil Chemists'Society. Champaign: AOCS, 2004.

BLONDEAU, N.; SCHNEIDER, S. Les acides gras essentiels de la famille des oméga-3 et la santé de la mère et de l'enfant. Nutrition Clinique et Métabolisme, v. 20, n. 2, p. 68-72, 2006.

BORDIGNON, S. R.; AMBROSANO, G. M. B.; RODRIGUES, P. H. V. In vitro propagation of sacha inchi. Ciência Rural, v. 42, n. 7, p. 1168-1172, 2012.

CARDOSO, A. A. et al. Environmental factors on seed germination, seedling survival and initial growth of sacha inchi (Plukenetia volubilis L.). Journal of Seed Science, v. 37, n. 2, p. 111-116, 2015.
CÉSPEDES, I. E. I. M. Situación y avances del cultivo de sacha inchi en el Peru. 2006. Available at: <http://www. incainchi.es/pdf/1358.pdf>. Access on: 25 Jun., 2016.

FOLLEGATTI-ROMERO, L. A. et al. Supercritical $\mathrm{CO}_{2}$ extraction of omega-3 rich oil from sacha inchi (Plukenetia volubilis L.) seeds. The Journal of Supercritical Fluids, v. 49, n. 3, p. 323-329, 2009.

GUILLÉN, M. D. et al. Characterization of sacha inchi (Plukenetia volubilis L.) oil by FTIR spectroscopy and $1 \mathrm{H}$ NMR: comparison with linseed oil. Journal of the American Oil Chemists'Society, v. 80, n. 8, p. 755-762, 2003.

GUTIÉRREZ, L. F.; ROSADA, L. M.; JIMÉNEZ, Á. Chemical composition of sacha inchi (Plukenetia volubilis L.) seeds and characteristics of their lipid fraction. Grasas y Aceites, v. 62, n. 1, p. 76-83, 2011.

HARTMAN, L.; LAGO, R. C. A. Rapid preparation of fatty acid methyl esters from lipids. Laboratory Practice, v. 22 , n. 6 , p. $475-477,1973$.

HUAMÁN, J. et al. Efecto de la Plukenetia volubilis Linneo (sacha inchi) en la trigliceridemia posprandial. Anales de la Facultad de Medicina, v. 69, n. 4, p. 263266, 2008.

KRIVANKOVA, B. et al. Sacha inchi (Plukenetia volubilis, Euphorbiaceae): a promising oilseed crop from Peruvian Amazon. In: CONFERENCE ON INTERNATIONAL AGRICULTURAL RESEARCH AND DEVELOPMENT, 1., 2007, Witzenhausen. Proceedings... Witzenhausen: Tropentag, 2007.

MAURER, N. E. et al. Characterization and authentication of a novel vegetable source of omega-3 fatty acids, sacha inchi (Plukenetia volubilis L.) oil. Food Chemistry, v. 134, n. 2, p. 1173-1180, 2012.

MULAMBA, N. N.; MOCK, J. J. Improvement of yield potential of the Eto Blanco maize (Zea mays L.) population by breeding for plant traits. Egyptian Journal of Genetics and Cytology, v. 7, n. 1, p. 40-57, 1978.

NATIONAL INSTITUTE OF STANDARDS AND TECHNOLOGY (NIST). NIST mass spectral search for the NIST/EPA/NIH mass spectral library version 2.0. Gaithersburg: NIST, 2005.

OLIVEIRA, E. J. et al. Genetic parameters and prediction of genotypic values for root quality traits in cassava using REML/BLUP. Genetics and Molecular Research, v. 13, n. 3, p. 6683-6700, 2014.

OLIVEIRA, S. A. G. et al. Estimation of genetic parameters of Plukenetia volubilis L. seed germination. Revista de Ciências Agrárias, v. 56, n. 1, p. 49-54, 2013.

RAMAPRASAD, T. R. et al. Spray-dried milk supplement with $\alpha$-linolenic acid and eicoesapentaenoic acid and docosahexaenoic acid decreases HMG CoA reductase 
activity and increases biliary secretion of lipds in rats. Steroids, v. 71, n. 5, p. 409-415, 2006.

RESENDE, M. D. V. Software Selegen - REML/BLUP: sistema estatístico e seleção genética computadorizada via modelos lineares mistos. Colombo: Embrapa Florestas, 2007.

RODRIGUES, H. S. et al. Genetic diversity of sacha inchi accessions detected by AFLP molecular markers. Revista de Ciências Agrárias, v. 56, n. 1, p. 55-60, 2013.
RODRIGUES, P. H. V.; BORDIGNON, S. R.; AMBROSANO, G. M. B. Horticultural performance of in vitro propagated plants of sacha inchi. Ciência Rural, v. 44, n. 6, p. 1050-1053, 2014.

YANG, C. et al. Germplasm characteristics of Plukenetia volubilis var. Brazilian and its productive performance after introduction into Yuanjiang Dry-Hot Valley of Yunnan, China. Botanical Research, v. 4, n. 1, p. 85-96, 2015. 